\title{
Satın Alma Tarzları ile Güç Mesafesi ve Bireycilik-Toplulukçuluk Arasındaki İlişki
}

\author{
Sezer AYAZ \\ Gençlik ve Spor Bakanlığ 1 \\ ayazsezer@hotmail.com \\ ORCID ID: 0000-0002-6374-8652 \\ Alphan ÇELIKKEL \\ Çiğli Özel Sağlık Tesisleri Tic. Ltd. Şti. \\ alphancelikel@hotmail.com \\ ORCID ID: 0000-0002-9722-8145
}

\begin{tabular}{lrr} 
Araştırma Makalesi & DOI: $10.31592 /$ aeusbed.690325 \\
\hline Geliş Tarihi: 17.02 .2020 & Revize Tarihi: 14.102020 & Kabul Tarihi: 03.11.2020
\end{tabular}

\section{Atıf Bilgisi}

Ayaz, S. ve Çelikel, A. (2020). Satın alma tarzları ile güç mesafesi ve bireycilik-toplulukçuluk arasındaki ilişki. Ahi Evran Üniversitesi Sosyal Bilimler Enstitüsü Dergisi, 6(3), 813-827

\section{ÖZ}

Tüketici karar verme tarzları daha önce birçok farklı örneklem kümesi ve farklı kültürde araştırılmıştır. Bu değişkeni, farklı bir evrende ve farklı bir değişken olan Hofstede'nin kültürel boyutları ile birlikte inceleyerek iliş̧ilerini ortaya koymaya çalışmak bu araştırmanın önemidir. Bu araştırmada, Uşak Üniversitesinde çalışan, eğitim gören veya eğitmenlik yapan belirli yaş aralığındaki bireylerin giyim satın alma alışkanlıkları ile Geert Hotsfede'nin Kültürel Boyutlar teorisi içindeki iki parametre olan Güç Mesafesi ve Bireycilik-Toplulukçuluk arasındaki ilişki incelenmiştir. Veriler anket formu yoluyla elde edilmiştir. Cevaplayıcılar satın alma tarzlarına göre beş gruba ayrılmıştır. Verilerin çözümlenmesi için betimleyici istatistik, tek yönlü varyans analizi (ANOVA) ve Pearson korelasyon analizi yapılmıştır. Analizler ve testler sonucunda, farklı gruplara ait cevaplayıcıların satın alma kararları ile ilgili demografik niteliklere göre anlamlı farklılıklar bulunmuş ve Hofstede'nin kültürel boyutları ile tüketici tarzları envanteri boyutları arasında $\mathrm{p}<.01$ düzeyinde pozitif yönlü ilişki olduğu belirlenmiştir. Elde edilen sonuçlar, hem giyim sektörüne yeni pazarlama ve satış stratejileri konusunda hem de akademisyenlere bu konuda yeni çalışmalar yapma konusunda kaynak olma niteliği taşımaktadır.

Anahtar Kelimeler: Satın alma tarzları, güç mesafesi, bireycilik- toplulukçuluk.

\section{The Relationship Between The Purchasing Styles and Power Distance and Individualism-Collectivism}

\begin{abstract}
Consumer decision making styles have been investigated in many different sample sets and different cultures before. Trying to reveal their relationship by examining this variable in a different universe and with cultural dimensions of Hofstede, which is a different variable, reflects the importance of the research. In this research, the relationship between purchasing clothing habits individuals in certain age ranges who work, study or educating at Uşak University and two parameters (Power Distance and Individualism-Collectivism) in Geert Hofstede's Cultural Dimensions theory was examined. The data were obtained through the questionnaire forms. Respondents are divided into five groups according to their purchase style. Descriptive statistics, oneway analysis of variance (ANOVA) and Pearson Correlation analysis were performed to analyze the data. As a result of the analyzes and tests, significant differences were found according to the demographic qualities regarding the purchasing decisions of the respondents belonging to different groups. It has been determined that there is a positive relationship between the cultural dimensions of Hofstede and the consumer style inventory dimensions at the level of $\mathrm{p}<.01$. The results obtained are both sources for new marketing and sales strategies for the clothing industry and for academicians to make new studies on this subject.

Keywords: Purchasing styles, power distance, individualism-collectivism.
\end{abstract}

\section{Giriş}

Dünyada her alanda değişim hızı arttıkça, bireylerin etkilendikleri fiziksel ve psikolojik öğeler de çoğalmıştır. Bireylerin kararlarını etkileyen psikolojik etmenlerden Geert Hofstede'nin Kültürel Boyutlar teorisi birçok endüstri için araştırma kaynağ 1 olmuştur. Kültürel boyutlar, giyim sektöründe de pazarlama stratejilerini belirleyen karar vericilerin en çok dikkat ettikleri etmenlerin içinde yer almaktadır. Her hangi bir ürün ya da ürün grubunun satış başarısının birçok sebebi vardır. Bu sebepler 
fiziksel olabileceği gibi psikolojik de olabilmektedir. Kültürel boyutlar da bu aşamada devreye girmektedir. Dâhil olunan kültürün baskın özellikleri, tüketici davranışları üzerinde etkili olsa da her tüketiciyi aynı şekilde etkilememekte ve kültürel boyutların her biri tüketici veya tüketici gruplarında farklı etki uyandırabilmektedir.

Araştırmamızda Uşak Üniversitesine mensup katılımcıların mevcut kültürleri temelinde, kültürel boyutlardan güç mesafesi ve bireycilik-toplulukçuluk ile satın alma alışkanlıkları arasındaki ilişki gözlemlenmeye çalışılmıştır. İlgili boyutların niteliksel olarak yer aldığ 1 ölçekler kullanılmış ve bu nitelikler baz alınarak katılımcı tüketici bireylerin tutumlarının belirlenmesi amaçlanmıştır. Günümüze dek yapılan araştırmaların büyük bir kısmı, farklı örneklemler üzerinde Sproles ve Kendall (1986) tarafından geliştirilmiş olan Tüketici Tarzları Envanteri (TTE) boyutları kullanılarak tüketicilerin satın alma tarzlarını test etmek amacı ile yapılmışıı. Bu araştırmayı diğer araştırmalardan ayıran temel farklılık ise TTE boyutları ile Hofstede'nin kültürel boyutlarından olan güç mesafesi ve bireycilik-toplulukçuluk'un ilk defa birlikte incelenmesidir. Bu yolla, gözlemlenen veya belirlenmeye çalışılan değişkenleri değerlendirmeye, etki derecelerini ortaya koymaya ve birbirleri arasındaki ilişkileri ortaya çıkarmaya uğraşılmıştır. Bu araştırmanın bulguları daha sonra yapılacak olan benzer çalışmalar için literatürde öncü ve kaynak niteliği taşıyacaktır.

\section{Satın Alma Tarzları}

Tüketicilerin mal ve hizmetleri tercih ederken gösterdiği tutum ve hareketler bütünü olarak tanımlanabilen (Odabaşı, 2002) tüketici davranışları üzerine birçok bilimsel çalışma yapılmıştır. Bu çalışmaların ortak hedefi, tüketicilerin satın alma kararlarını etkileyen faktörleri belirlemeye çalışıp tüketicileri gruplandırmak ve elde edilen bulgulara göre ürün veya hizmet için en uygun pazarlama stratejilerini belirlemektir. Gruplandırmalar yapılırken demografik, sosyo-ekonomik, psikolojik, coğrafik vb. unsurlar göz önünde bulundurularak çeşitli şekillerde yapılabilmektedir. Bu gruplandırma kriterlerinden biri de bireylerin satın alma sürecindeki karar verme tarzlarıdır. Sproles ve Kendall (1986) bu konuda etkisini günümüzde de sürdüren en önemli araştırmalardan birini yapmışlardır.

Sproles ve Kendall (1986), tüketici karar verme tarzını bir tüketicinin karar verme tutumunu nitelendiren zihinsel yönelim şeklinde açıkladıkları çalışmalarında, literatürde o zamana kadar tanımlanan tüketici karar verme nitelikleri arasından duygusal ve bilişsel özellikleri birlikte içeren en temel sekiz zihinsel özelliği saptamıştır. Yazarlar, bu karar verme tarzı niteliklerini ölçebilmek amaciyla bir "Tüketici Tarzları Envanteri” oluşturmayı hedeflemişlerdir. Yürüttükleri araştırmalar sonucunda sekiz ana boyut ve toplam 40 yargıdan oluşan bir "Tüketici Tarzları Envanteri” (TTE) ortaya çıkarmışlardır. TTE şu boyutları kapsamaktadır:

$>\quad$ Mükemmeliyetçilik-Yüksek kalite odaklılık: En iyi ürünü sahip olmak için sıkı bir araştırmaya girişme

> Marka odaklılık: Daha pahalı, bilinirliği fazla olan markaları tercih etme

$>$ Yenilik-Moda odaklılık: Yeni şeyler aramaktan ve modayı takip etmekten hoşlanma

$>\quad$ Eğlence-Haz odaklılık: Alışverişten zevk alma ve eğlence olsun diye alışveriş yapma

Fiyat odaklılık: İndirimleri izleme, ödediği miktarın tam karşılığını bekleme

Düşünmeden alışveriş etme-Dikkatsizlik: Plansız ve özensiz alışveriş etme

Çeşit karmaşası yaşama: Marka, mağaza ve bilgi çokluğundan karar verme güçlüğü yaşama

> Alışkanlık- Marka bağlılığı odaklılık: Sevilen marka ve mağazaların olması ve bunlardan satın almayı alışkanlık haline getirme. Yazarlara göre tüketicilerin karar verme tarzları çoğu zaman bu niteliklerin bir birleşimi ile özellikle de bir veya ikisinin baskınlığıyla ortaya çıkmaktadır.

TTE'nin genellenebilirliğinin test edildiği ilk araştırmalarda Sproles ve Kendall'ın (1986) kullandığı yöntemin benzeri uygulanarak edinilen bulgular orijinal faktör yapısı ile karşılaştırılmıştır. 
$\mathrm{Bu}$ araştırmalarda ölçeğin faktör sayıları, yargıların yüklendikleri faktörler ve faktör güvenilirlikleri ile ilgili bulgular, muhtemelen ekonomik ve kültürel temelli bazı faklılıklar olmakla birlikte orijinal TTE ile benzer faktör yapılarının varlığını ortaya koymuştur (Hafstrom, Chae ve Chung,1992; Darvasula, Lysonski ve Andrews, 1993; Lysonski, Durvasula ve Zotos, 1995; Mitchell ve Bates, 1998; Fan ve Xiao, 1998; Walsh, Mitchell ve Thurau, 2001; Hiu, Siu, Wang ve Chang, 2001; Ünal ve Erciş, 2006; Kavas ve Yeşilada, 2007). Kısa zaman önce bu ölçeğin Türkiye'deki tüketici bireyler üzerinde uygulanmasına yönelik yapılan bir araştırmada, ölçeğin bazı uyarlamalar yapıldıktan sonra Türkiye'de yaşayan tüketiciler için de efektif bir gruplama ve kümeleme aracı olabileceği kanıtlanmıştır. (Dursun, Alnıaçı ve Tümer Kabadayı, 2013).

\section{Güç Mesafesi}

Kimi topluluk ve kültürlerde daha az gücü olan insanlar, eşit olmayan güç dağılımını sindirmişlerdir. Diğer bir ifadeyle toplumdaki bireylerin arasındaki güç mesafesi fazladır (Sargut, 2001). Güç mesafesi, bir toplulukta görece daha az güce sahip olan bireylerin gücün dağılımının eşit olmadığına kanaat getirmesidir. Geniş güç mesafesine sahip topluluklarda bireyler kendilerine ait özel alanlara sahiplerdir ve bu alanda statülerini kullanırlar, dar güç mesafesine sahip toplumlarda ise gücü olan bireyler kendilerini daha güçsüz gösterme eğilimdedirler (Mooij ve Hotsfede, 2002). Örgütsel olarak bakıldığında ise gücün tek merkezde toplanması tercih edilmektedir. Bundan dolayı çalışanlar yöneticilerinin kendileri için oluşturdukları alanda dururlar ve emirleri beklerler (Rodrigues, 1988). Geniş güç mesafesine sahip toplumlarda, örgüt içerisindeki güç dağılımı dengesizliklere ve eşitsizliklere neden olabilmektedir. Böyle kültürlerde, pozisyon, statü, unvan gibi özelliklere sayg1 gösterilir ve önem verilir. Dar güç mesafesine sahip kültürlerdeyse, aksi durum söz konusudur; örgütlerde önemli kararlar alınacağı zaman alt kademedeki bireylerin de dâhil olması istenmekte, düşünceleri dinlenmekte ve bu yolla güç dağllımında eşitsizlikler daha az görülmektedir. Dar güç aralığına örnek toplumlar olarak Avusturya, İ̀rail, Danimarka, Yeni Zelanda ve İrlanda, geniş güç aralığına ise Malezya, Panama, Guetamala, Filipinler, Türkiye ve Venezuela örnek gösterilebilmektedir.

\section{Bireycilik-Toplulukçuluk}

Hofstede toplumları bireyci ve toplulukçu olarak iki ayrı boyutta ele almıştır. Bireycilik ve toplulukçuluk, bireylerin ruhunun kendilerine mi yoksa sağlam bağlarla biri birine örülü bir topluluğa mı dönük olduğunun cevabını vermeye çalışmaktadır (Steger, Schindel ve Krapf, 2002). Toplulukçuluk mantığı taşıyan gruplarda bireyler aileye, örgüte, işletmeye karşı aidiyet duygusu taşımaktadırlar ve ilgili yapının bir öğesi gibi hareket etmektedirler. Bu nedenle topluluğun faydası bireyin edineceği faydadan daha fazla önem taşımaktadır. Panama, Guatemala, Venezuela, Ekvator gibi ülkeler toplulukçuluğun örnekleri olarak gösterilebilmektedir. Türkiye ise Hofstede'nin (1984) araştırmasında yüksek toplulukçuluk düzeyinde gösterilmiştir. Bireyci toplumlarda ise ben fikri ağır basmaktadır. Ben düşüncesinin ön planda olduğu bu toplumlarda bireyler alınan kararlarda kendileri birebir etkin olmayı arzu etmektedirler. Bireysel başarıların daha fazla önem taşıdığ bu gruplara İngiltere, Amerika, Avustralya, Kanada gibi Anglo-Sakson ülkeler örnek gösterilebilmektedir.

\section{Yöntem}

$\mathrm{Bu}$ araştırma ilişkisel tarama modeli ile tasarımlanmış nicel bir çalışmadır. İlişkisel tarama modelleri birden fazla sayıda değişken arasındaki değişimin varlığı ve düzeyini saptamayı amaçlamaktadır (Karasar, 2018). Araştırmada kullanılan model ile TTE boyutlarından beş boyut; mükemmeliyetçilik, eğlence ve haz odaklılık, yenilik-moda odaklılık, çeşit karmaşası ve markaya duyarlılık ile Hofstede'nin kültürel boyutlarından bireycilik-toplulukçuluk ve güç mesafesi arasındaki ilişki ölçülmektedir. Çalışmanın temel amacı Uşak Üniversitesi örnekleminde Hofstede'nin kültürel boyutları ile tüketicilerin satın alma tarzları arasında ilişki olup olmadığını incelemektir. Alt amaç ise ilgili boyutların katılımcıların demografik özellikleri itibari ile farklılaşıp farklılaşmadığını ortaya koymaktır. 


\section{Evren ve Örneklem}

$\mathrm{Bu}$ araştırmada kolayda örnekleme metodu tercih edilmiştir. Örneklemin ana kütleyi daha iyi temsil edebilmesi için ve daha heterojen bir yapıya ulaşarak genelleştirilebilirlik oranının artırılması amacıyla çoğu araştırmadan farklı bir şekilde toplamda yaklaşık 25 bin öğrenci, çalışan ve eğitmenden oluşan evrenden rastgele 750 kişilik geniş bir örneklem çerçevesi ortaya konulmuştur. Örneklem adedinin ölçekte kullanılan madde sayısının en az 5 katı olması gerektiği araştırmacılar tarafından genel kabul gören yaklaşımdır (Büyüköztürk, Kılıç Çakmak, Akgün, Karadeniz ve Demirel, 2014; Tavşanc1l, 2006). Anket uygulama sonucunda 463 kişi anketleri cevaplamış, bu anketlerden 83'ü eksiklikler ve tutarsızlıklar sebebi ile elenmiş toplamda 380 örneklem analiz ve testlere tabi tutulmuştur. Ulaşılan örneklem sayısı, ölçekteki 38 maddenin on katı büyüklüğünde olduğundan dolayı istatistiksel işlemler için gayet iyi bir sayıya ulaşıldığı söylenebilir. Tablo1'de örnekleme dair demografik özellikler, yüzde oranı ve sıklıklar ile görülebilmektedir.

Tablo 1

Demografik Özellikler

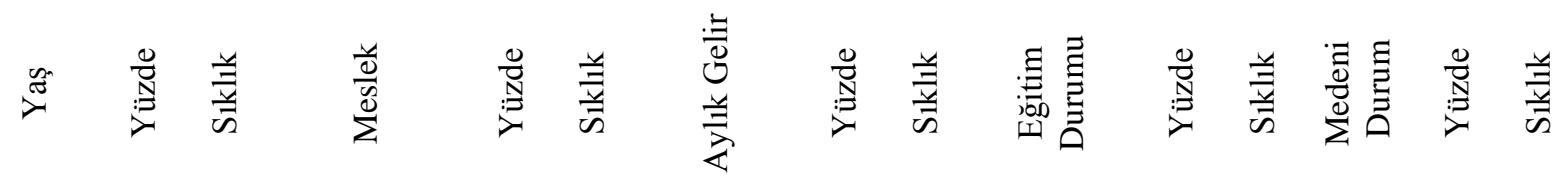

\begin{tabular}{ccccccccccccccc}
\hline $18-25$ & 23.7 & 90 & İşçi & 15.8 & 60 & $\begin{array}{c}1404 \mathrm{TL} \\
\text { ve altı }\end{array}$ & 21.8 & 83 & İlköğretim & 6.1 & 23 & Evli & 55.5 & 211 \\
$26-33$ & 32.4 & 123 & Memur & 38.4 & 146 & $1404-$ & 15.0 & 57 & Lise & 18.4 & 70 & Bekâr & 44.5 & 169 \\
$34-41$ & 18.9 & 72 & Esnaf & 2.1 & 8 & $\begin{array}{c}2001- \\
3000 \mathrm{TL}\end{array}$ & 25.5 & 97 & Önlisans & 17.1 & 65 & & & \\
$42-49$ & 14.5 & 55 & $\begin{array}{c}\text { Serbest } \\
\text { meslek }\end{array}$ & 4.2 & 16 & $\begin{array}{c}3001- \\
4000 \mathrm{TL}\end{array}$ & 15.8 & 60 & Lisans & 42.4 & 161 & & & \\
$50-57$ & 8.4 & 32 & Öğrenci & 15.3 & 58 & $\begin{array}{c}4001- \\
5000 \mathrm{TL}\end{array}$ & 7.6 & 29 & Lisansüstü & 16.1 & 61 & & & \\
$58-65$ & 1.3 & 5 & Çalışmıyor & 9.7 & 37 & $\begin{array}{c}5000 \mathrm{TL} \\
\text { ve üzeri }\end{array}$ & 14.2 & 54 & & & & & & \\
$66+$ & .8 & 3 & Diğer & 14.5 & 55 & & & & & & & & & \\
Toplam & 100 & 380 & & 100 & 380 & & 100 & 380 & & 100 & 380 & & 100 & 380 \\
\hline
\end{tabular}

\section{Veri Toplama Aracı}

Çalışmada, Sproles ve Kendall'ın 1986 yılında tüketicilerin karar verme tarzlarını belirlemek için tanımlamış olduğu sekiz temel özellikten oluşan Tüketici Tarzları Envanteri (TTE) ölçeği'nden kuramsal olarak uzmanlar çerçevesinden uygun olduğu düşünülen beş boyut ve Yoo, Donthu ve Lenartowicz (2011) tarafından Hofstede'nin beş boyutlu kültürel değerler ölçeğinden uyarlanarak oluşturulan beş boyuttan ikisi kullanılmıştır.

Ölçek toplam 38 madde ve 7 boyuttan oluşmaktadır. Her iki ölçekteki yargılar 5'li likert (1:Kesinlikle Katılmıyorum, 2:Katılmıyorum, 3:Kararsızım, 4:Katılıyorum, 5:Kesinlikle Kat1lyorum) ile derecelendirilmiştir. 


\section{Verilerin Analizi}

Veriler anket formu yoluyla elde edilmiştir. Cevaplayıcılar satın alma tarzlarına göre beş gruba ayrılmıştır. Verilerin çözümlenmesi için betimleyici istatistik yöntemi kullanılmıştır. Araştırma sorularına karşılık katılımcıların verdikleri cevaplara ilişsin frekans (f) ve yüzde (\%) değerlerinin hesaplanmasının yanı sira tek yönlü varyans analizi (ANOVA) ve Pearson korelasyon analizi yapılmıştır. Verilerin kolay anlaşılabilmesi ve yorumlanabilmesi adına bulgular yeterli ayrıntı düzeyinde tablolaştırılarak sunulmuştur.

\section{Araștırma Etiği}

Çalışmanın bilgilendirilmiş gönüllü onam formu ve etik kurul onamı alınmıştır. (Uşak Üniversitesi Rektörlüğü, Sosyal ve Beşeri Bilimler Bilimsel Araştırma ve Yayın Etiği Kurulu. Tarih: 06.03.2020, Karar No: 2020-28).

\section{Bulgular}

Çalışmanın ölçme aracı ile edinilen verilerin çözümlemesinde demografik bilgilere ulaşmak için betimsel istatistik yöntemlerine (yüzde, frekans, standart sapma, ortalama) başvurulmuştur. Normallik dağılımını belirlemek için sosyal bilimlerde sıkça başvurulan istatistiksel analiz yöntemiyle çarpıklık ve basıklık katsayılarına ulaşılmış, tüm çarpıklık ve basıklık katsayılarının +1 ile -1 arasında olduğu (Hair, Black, Babin, Anderson ve Tatham, 2013) ve dolayısıyla normal dağıldığı görülmüsstür.

Tablo 2'de görüldüğü gibi ölçme aracındaki iç tutarlılık güvenilirliklerini test edebilmek için hesaplanan Cronbach's Alfa iç tutarlılık katsayısının hesaplanması sonucu ilgili 7 faktörün sosyal bilimlerde kabul gören $>.60$ güvenirlik değerinin üstünde olduğu görülmüştür. .60 ve üzerindeki değerler sosyal bilimlerde uygulanan araştırmalar için kabul edilebilir güvenilirlik değer aralıklarıdır (Nunnally, 1967).

Tablo 2

İç Tutarlılık ve Normallik Dă̆glımı Sonuçları

\begin{tabular}{|c|c|c|c|c|c|c|c|c|}
\hline & 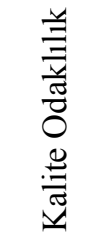 & 吾 & $\begin{array}{l}\text { 当 } \\
\bar{z} \\
\frac{\pi}{0} \\
0 \\
0 \\
\frac{\pi}{0} \\
\sum\end{array}$ & 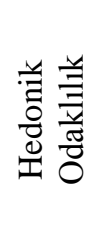 & 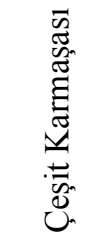 & 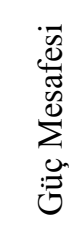 & 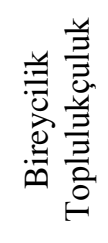 & $\begin{array}{l}\frac{y}{0} \\
: \overline{0} \\
\Xi \\
\vdots \\
\vdots\end{array}$ \\
\hline A & .678 & .783 & .744 & .650 & .849 & .802 & .840 & .817 \\
\hline Çarpıklık & .197 & .449 & .135 & .274 & -.028 & .679 & -.253 & \\
\hline Basıklık & -.458 & .153 & -.116 & .483 & -.588 & .191 & -.131 & \\
\hline
\end{tabular}

Katılımcıların demografik niteliklerine göre ölçek maddelerindeki farklılıkları incelemek amacıyla ilişkisiz örneklemler için t-testi ve tek faktörlü ANOVA istatistiksel yöntemi kullanılmıştır (Büyüköztürk, 2002). Değiş̧kenler arası ikili ilişkiyi ölçmek amacıyla pearson korelasyon analizine başvurulmuştur.

Tablo 3

Katılımcıların Ölçüm Aracında Yer Alan Faktör Düzeyleri Üzerinden Medeni Durumlarına Göre Karşılaştırılmaları İçin t Testi

\begin{tabular}{cccccccc}
\hline & Grup & $\mathrm{N}$ & Ortalama & $\begin{array}{c}\text { Standart } \\
\text { Sapma }\end{array}$ & $\mathrm{t}$ & $\mathrm{df}$ & $\mathrm{p}^{*}$ \\
\hline \multirow{2}{*}{ Kalite Odaklılık } & Evli & 211 & 3.13 & .55012 & -.907 & 378 & .365 \\
& Bekâr & 169 & 3.18 & .54504 & & & \\
Marka Odaklılık & Evli & 211 & 2.45 & .71204 & -.952 & 378 & .342
\end{tabular}




\begin{tabular}{lccccccc} 
Moda Odaklılık & Evli & 211 & 2.85 & .78791 & -2.639 & 378 & $.009 *$ \\
& Bekâr & 169 & 3.07 & .83586 & & & \\
Hedonik Odaklılık & Evli & 211 & 2.89 & .61792 & -.090 & 378 & .929 \\
& Bekâr & 169 & 2.90 & .58069 & & & \\
Çeşit Karmaşası & Evli & 211 & 3.07 & 1.00501 & 1.453 & 378 & .147 \\
Güç Mesafesi & Bekâr & 169 & 2.93 & .95455 & & & \\
& Evli & 211 & 2.00 & .77250 & .735 & 378 & .463 \\
& Bekâr & 169 & 1.94 & .80391 & & & \\
& Evli & 211 & 3.69 & .82644 & 2.363 & 378 & $.019^{*}$ \\
& Bekâr & 169 & 3.49 & .75404 & & & \\
\hline
\end{tabular}

$* \mathrm{p}<0.05$

Araştırmada yer alan evli ve bekâr katılımcılar arasında yedi faktörden ikisi olan moda odaklılık $(\mathrm{p}=.009)$ ve bireycilik-toplulukçuluk $(\mathrm{p}=.019)$ faktörlerinde anlamlı farklılık bulunmuş, diğer beş faktörde medeni duruma göre anlamlı farklılık bulunamamıştır. Tablo 3'te anlamlı farklılıklara ait ilgili değerler gösterilmiştir. Buna göre bekâr katılımcıların $(\overline{\mathrm{X}}=3.0698)$ moda odaklılık düzeyleri evli katılımcılara $(\overline{\mathrm{X}}=2.8493)$ göre anlamlı derecede yüksektir. Evli katılımc1ların $(\overline{\mathrm{X}}=3.6863)$ bireyciliktoplulukçuluk düzeyleri bekâr katılımcılara $(\overline{\mathrm{X}}=3.4923)$ göre anlamlı derecede daha yüksektir.

Tablo 4

Katılımcıların Ölçüm Aracında Yer Alan Faktör Düzeyleri Üzerinden Yaş Gruplarına Göre Karşılaş̧tırılmaları İçin Anova Testi

\begin{tabular}{|c|c|c|c|c|c|c|}
\hline Faktör & & $\begin{array}{l}\text { Kareler } \\
\text { Toplamı }\end{array}$ & sd & $\begin{array}{c}\text { Kareler } \\
\text { Ortalaması }\end{array}$ & $\mathrm{F}$ & $\mathrm{p}$ \\
\hline \multirow{3}{*}{ Kalite Odaklılık } & Kümeler Arası & 1.710 & 6 & .285 & .949 & .460 \\
\hline & Kümeler İçi & 111.997 & 373 & .300 & & \\
\hline & Toplam & 113.706 & 379 & & & \\
\hline \multirow{3}{*}{ Marka Odaklılık } & Kümeler Arası & 5.921 & 6 & .987 & 1.860 & .087 \\
\hline & Kümeler İçi & 197.938 & 373 & .531 & & \\
\hline & Toplam & 203.858 & 379 & & & \\
\hline \multirow{3}{*}{ Moda Odaklılık } & Kümeler Arası & 20.532 & 6 & 3.422 & 5.507 & $.000 *$ \\
\hline & Kümeler İçi & 231.775 & 373 & .621 & & \\
\hline & Toplam & 252.307 & 379 & & & \\
\hline \multirow{3}{*}{ Hedonik Odaklılık } & Kümeler Arası & 2.443 & 6 & .407 & 1.130 & .344 \\
\hline & Kümeler İçi & 134.392 & 373 & .360 & & \\
\hline & Toplam & 136.835 & 379 & & & \\
\hline \multirow{3}{*}{ Çeşit Karmaşası } & Kümeler Arası & 4.734 & 6 & .789 & .812 & .561 \\
\hline & Kümeler İçi & 362.492 & 373 & .972 & & \\
\hline & Toplam & 367.226 & 379 & & & \\
\hline \multirow{3}{*}{ Güç Mesafesi } & Kümeler Arası & 8.908 & 6 & 1.485 & 2.458 & $.024 *$ \\
\hline & Kümeler İçi & 225.319 & 373 & .604 & & \\
\hline & Toplam & 234.227 & 379 & & & \\
\hline \multirow{3}{*}{ Bireycilik-Toplulukçuluk } & Kümeler Arası & 6.588 & 6 & 1.098 & 1.736 & .111 \\
\hline & Kümeler İçi & 235.892 & 373 & .632 & & \\
\hline & Toplam & 242.480 & 379 & & & \\
\hline
\end{tabular}

$* \mathrm{p}<0.05$

Çalışmaya katılan bireyler arasında yaş gruplarına göre yedi faktörden ikisi olan moda odaklılık $(\mathrm{p}=.000)$ ve güç mesafesi $(\mathrm{p}=.024)$ faktörlerinde anlamlı farklılık bulunmuş, diğer beş faktörde yaş gruplarına göre anlamlı farklılık tespit edilmemiştir. Tablo 4'te anlamlı farklılıklara ait ilgili değerler gösterilmiştir. Farkın hangi yaş kümesinden kaynaklandığının tespit edilmesi için yapılan Tukey testinin sonucuna göre 18-25 yaş kümesindeki katılımcıların $(\bar{X}=3.0978)$ ve 26-33 yaş kümesindeki katılımcıların ( $\overline{\mathrm{X}}=3.1252)$ moda odaklılık düzeylerinin 42-49 yaş kümesindekilerden $(\overline{\mathrm{X}}=2.5491)$ ve 50-57 yaş kümesindeki katılımcılardan $(\overline{\mathrm{X}}=2.5375)$ daha yüksek olduğu belirlenmiştir. Ayrıca 66 ve üstü yaş kümesindeki katılımcıların $(\overline{\mathrm{X}}=3.3333)$ güç mesafesi düzeylerinin $18-25$ yaş 
kümesindeki katılımcılardan $(\overline{\mathrm{X}}=1.9111)$ ve 26-33 yaş kümesindeki katılımcılardan $(\overline{\mathrm{X}}=1.8976)$ daha yüksek olduğu tespit edilmiştir.

Tablo 5

Katılımcıların Ölçüm Aracında Yer Alan Faktör Düzeyleri Üzerinden Öğrenim Durumlarına Göre Karşılaştırılmaları İçin Anova Testi

\begin{tabular}{|c|c|c|c|c|c|c|}
\hline Faktör & & $\begin{array}{l}\text { Kareler } \\
\text { Toplam1 }\end{array}$ & $\mathrm{sd}$ & $\begin{array}{c}\text { Kareler } \\
\text { Ortalamas1 }\end{array}$ & $\mathrm{F}$ & $\mathrm{p}$ \\
\hline \multirow{3}{*}{ Kalite Odaklılık } & Kümeler Aras1 & 3.447 & 4 & .862 & 2.931 & $.021 *$ \\
\hline & Kümeler İçi & 110.259 & 375 & .294 & & \\
\hline & Toplam & 113.706 & 379 & & & \\
\hline \multirow{3}{*}{ Marka Odaklılık } & Kümeler Arası & 2.651 & 4 & .663 & 1.235 & .295 \\
\hline & Kümeler İçi & 201.208 & 375 & .537 & & \\
\hline & Toplam & 203.858 & 379 & & & \\
\hline \multirow{3}{*}{ Moda Odaklılık } & Kümeler Arası & 3.679 & 4 & .920 & 1.387 & .238 \\
\hline & Kümeler İçi & 248.629 & 375 & .663 & & \\
\hline & Toplam & 252.307 & 379 & & & \\
\hline \multirow{3}{*}{ Hedonik Odakl11lk } & Kümeler Arası & 1.756 & 4 & 439 & 1.219 & .302 \\
\hline & Kümeler İçi & 135.079 & 375 & .360 & & \\
\hline & Toplam & 136.835 & 379 & & & \\
\hline \multirow{3}{*}{ Çeşit Karmaşası } & Kümeler Arası & 7.132 & 4 & 1.783 & 1.857 & .117 \\
\hline & Kümeler İçi & 360.094 & 375 & .960 & & \\
\hline & Toplam & 367.226 & 379 & & & \\
\hline \multirow{3}{*}{ Güç Mesafesi } & Kümeler Arası & 26.189 & 4 & 6.547 & 11.802 & $.000 *$ \\
\hline & Kümeler İçi & 208.038 & 375 & .555 & & \\
\hline & Toplam & 234.227 & 379 & & & \\
\hline \multirow{3}{*}{ Bireycilik-Toplulukçuluk } & Kümeler Arası & 11.878 & 4 & 2.970 & 4.829 & $.001 *$ \\
\hline & Kümeler İçi & 230.602 & 375 & .615 & & \\
\hline & Toplam & 242.480 & 379 & & & \\
\hline
\end{tabular}

$* \mathrm{p}<0.05$

Araştırmadaki katılımcılar arasında öğrenim durumlarına göre yedi faktörden üçü olan kalite odaklılık ( $\mathrm{p}=.021)$, güç mesafesi $(\mathrm{p}=.000)$ ve bireycilik-toplulukçuluk $(\mathrm{p}=.001)$ faktörlerinde anlamlı farkl11ık bulunmuş, diğer dört faktörde anlamlı farklılık bulunamamıştır. Tablo 5'te anlamlı farklılıklara ait katsayılar görülmektedir. Hangi öğrenim durumu kümeleri arasında farklılık olduğunu tespit etmek için yapılan Tukey testinin sonucuna göre lisans mezunu kümesindeki katılımcıların $(\overline{\mathrm{X}}=3.2166)$ kalite odakl11ık düzeyinin ilköğretim mezunu kümesindeki katılımc1lardan $(\overline{\mathrm{X}}=2.9348)$ anlamlı derecede yüksek olduğu saptanmıştır. İlköğretim mezunu kümesindeki katılımcıların $(\overline{\mathrm{X}}=2.4087)$ güç mesafesi düzeyinin lisans mezunu kümesindeki katılımcılardan $(\overline{\mathrm{X}}=1.7553)$ ve lisansüstü mezunu kümesindekilerden ( $\overline{\mathrm{X}}=1.7967)$ anlamlı derecede yüksek olduğu belirlenmiştir. Lise mezunu kümesindeki katılımcıların $(\overline{\mathrm{X}}=2.3686)$ güç mesafesi düzeyinin lisans mezunu kümesindeki kat1lımcilardan $(\bar{X}=1.7553)$ ve lisansüstü mezunu kümesindekilerden $(\bar{X}=1.7967)$ anlamlı düzeyde yüksek olduğu tespit edilmiştir. Önlisans mezunu kümesindeki katılımcıların $(\bar{X}=2.1169)$ güç mesafesi düzeyinin lisans mezunu kümesindeki katılımcilardan $(\overline{\mathrm{X}}=1.7553)$ daha yüksek olduğu belirlenmiştir. Ayrıca lisans mezunu kümesindeki katılımcıların ( $\overline{\mathrm{X}}=3.6398)$ ve lisansüstü mezunu kümesindekilerin $(\overline{\mathrm{X}}=3.8984)$ bireycilik-toplulukçuluk düzeyinin lise mezunu kümesindeki katılımcılardan $(\overline{\mathrm{X}}=3.3086)$ anlamlı düzeyde yüksek olduğu saptanmıştır.

Tablo 6

Katılımcıların Ölçüm Aracında Yer Alan Faktör Düzeyleri Üzerinden Meslek Gruplarına Göre Karșılaștırılmaları İçin Anova Testi

\begin{tabular}{|c|c|c|c|c|c|c|}
\hline Faktör & & $\begin{array}{c}\text { Kareler } \\
\text { Toplamı }\end{array}$ & sd & $\begin{array}{c}\text { Kareler } \\
\text { Ortalaması }\end{array}$ & $\mathrm{F}$ & $\mathrm{p}$ \\
\hline \multirow{3}{*}{ Kalite Odaklılık } & Kümeler Arası & 4.439 & 6 & .740 & 2.525 & $.021 *$ \\
\hline & Kümeler İçi & 109.268 & 373 & .293 & & \\
\hline & Toplam & 113.706 & 379 & & & \\
\hline
\end{tabular}




\begin{tabular}{|c|c|c|c|c|c|c|}
\hline \multirow{3}{*}{ Marka Odaklıl1k } & Kümeler Arası & 3.365 & 6 & .561 & 1.043 & .397 \\
\hline & Kümeler İçi & 200.494 & 373 & .538 & & \\
\hline & Toplam & 203.858 & 379 & & & \\
\hline \multirow{3}{*}{ Moda Odaklılık } & Kümeler Arası & 6.732 & 6 & 1.122 & 1.704 & .119 \\
\hline & Kümeler İçi & 245.575 & 373 & .658 & & \\
\hline & Toplam & 252.307 & 379 & & & \\
\hline \multirow{3}{*}{ Hedonik Odakl1l1k } & Kümeler Arası & 2.921 & 6 & 487 & 1.356 & .231 \\
\hline & Kümeler İçi & 133.914 & 373 & .359 & & \\
\hline & Toplam & 136.835 & 379 & & & \\
\hline \multirow{3}{*}{ Çeşit Karmaşası } & Kümeler Arası & 48.777 & 6 & 8.129 & 9.522 & $.000 *$ \\
\hline & Kümeler İçi & 318.449 & 373 & .854 & & \\
\hline & Toplam & 367.226 & 379 & & & \\
\hline \multirow{3}{*}{ Güç Mesafesi } & Kümeler Arası & 19.106 & 6 & 3.184 & 5.521 & $.000 *$ \\
\hline & Kümeler İçi & 215.121 & 373 & .577 & & \\
\hline & Toplam & 234.227 & 379 & & & \\
\hline \multirow{3}{*}{ Bireycilik-Toplulukçuluk } & Kümeler Arası & 11.321 & 6 & 1.887 & 3.045 & $.006 *$ \\
\hline & Kümeler İçi & 231.159 & 373 & .620 & & \\
\hline & Toplam & 242.480 & 379 & & & \\
\hline
\end{tabular}

$* \mathrm{p}<0.05$

Katılımcılar arasında meslek gruplarına göre kalite odaklılık $(\mathrm{p}=.021)$, çeşit karmaşası $(\mathrm{p}=.000)$, güç mesafesi $(\mathrm{p}=.000)$ ve bireycilik-toplulukçuluk $(\mathrm{p}=.006)$ faktörlerinde anlamlı farklılık bulunmuş, diğer üç faktörde meslek gruplarına göre anlamlı farklılık bulunamamıştır. Tablo 6'te anlamlı farklılık değerleri gösterilmiştir. Hangi meslek grupları arasında farklılık olduğu bilgisine ulaşabilmek adına yapılan Tukey testinin sonucuna göre memur grubundaki katılımcıların $(\overline{\mathrm{X}}=3.2286)$ kalite odakl1lık düzeyinin işçi grubundaki katılımcılardan $(\bar{X}=2.9688)$ anlamlı derecede yüksek olduğu belirlenmiştir. Çalışmayan kümesindeki katılımcıların ( $\bar{X}=3.5743)$ ve öğrenci kümesindeki katılımcıların $(\overline{\mathrm{X}}=3.3534)$ çeşit karmaşası düzeyinin diğer diye tanımlanan meslek gruplarına mensup katılımcılardan $(\overline{\mathrm{X}}=2.4500)$, serbest meslek grubu katılımcılardan $(\overline{\mathrm{X}}=2.5000)$ ve işçi grubundaki katılımcılardan ( $\overline{\mathrm{X}}=2.6750)$ anlamlı derecede yüksek olduğu saptanmıştır. Memur kümesindeki katılımcıların $(\overline{\mathrm{X}}=3.1267)$ çeşit karmaşası düzeyinin işçi grubundaki katılımcılardan $(\overline{\mathrm{X}}=2.6750)$ ve diğer diye tanımlanan meslek gruplarına mensup katılımcılardan $(\overline{\mathrm{X}}=2.4500)$ anlamlı derecede yüksek olduğu belirlenmiştir. Esnaf grubundaki katılımcıların $(\overline{\mathrm{X}}=2.6750)$ güç mesafesi düzeyinin memur grubundaki katılımcılardan $(\overline{\mathrm{X}}=1.8397)$ ve diğer diye tanımlanan meslek gruplarına mensup katılımcılardan ( $\overline{\mathrm{X}}=1.8182)$ anlamlı derecede yüksek olduğu görülmüsstür. İşçi grubundaki katılımcıların $(\bar{X}=2.3700)$ güç mesafesi düzeyinin öğrenci grubundaki katılımcılardan $(\bar{X}=1.9034)$, memur grubundaki katılımcilardan $(\overline{\mathrm{X}}=1.8397)$ ve diğer diye tanımlanan meslek gruplarına mensup katılımcılardan $(\bar{X}=1.8182)$ anlamlı derecede yüksek olduğu belirlenmiştir. Memur grubundaki katılımcıların ( $\overline{\mathrm{X}}=3.7753)$ bireycilik-toplulukçuluk düzeyinin öğrenci grubundaki katılımcılardan $(\overline{\mathrm{X}}=3.3467)$ ve işçi grubundaki katılımcılardan $(\overline{\mathrm{X}}=3.3931)$ anlamlı derecede yüksek olduğu görülmüştür.

Tablo 7

Katılımcıların Ölçüm Aracında Yer Alan Faktör Düzeyleri Üzerinden Gelir Düzeylerine Göre Karşılaştırılmaları İçin Anova Testi

\begin{tabular}{|c|c|c|c|c|c|c|}
\hline Faktör & & $\begin{array}{l}\text { Kareler } \\
\text { Toplamı }\end{array}$ & sd & $\begin{array}{c}\text { Kareler } \\
\text { Ortalamas1 }\end{array}$ & $\mathrm{F}$ & $\mathrm{p}$ \\
\hline \multirow{3}{*}{ Kalite Odaklılık } & Kümeler Arası & 6.592 & 5 & 1.318 & 4.604 & $.000 *$ \\
\hline & Kümeler İçi & 107.114 & 374 & .286 & & \\
\hline & Toplam & 113.706 & 379 & & & \\
\hline \multirow{3}{*}{ Marka Odaklılık } & Kümeler Arası & 6.438 & 5 & 1.288 & 2.439 & $.034 *$ \\
\hline & Kümeler İçi & 197.421 & 374 & .528 & & \\
\hline & Toplam & 203.858 & 379 & & & \\
\hline \multirow{3}{*}{ Moda Odaklılık } & Kümeler Arası & 4.048 & 5 & .810 & 1.220 & .299 \\
\hline & Kümeler İçi & 248.259 & 374 & .664 & & \\
\hline & Toplam & 252.307 & 379 & & & \\
\hline Hedonik Odaklılık & Kümeler Arası & 1.665 & 5 & .333 & .922 & .467 \\
\hline
\end{tabular}




\begin{tabular}{ccccccc} 
& Kümeler İçi & 135.169 & 374 & .361 & & \\
& Toplam & 136.835 & 379 & & & \\
& Kümeler Arası & 19.593 & 5 & 3.919 & 4.216 & $.001^{*}$ \\
Çeşit Karmaşası & Kümeler İçi & 347.633 & 374 & .930 & & \\
& Toplam & 367.226 & 379 & & & .085 \\
Güç Mesafesi & Kümeler Arası & 5.951 & 5 & 1.190 & 1.950 & $.001 *$ \\
& Kümeler İçi & 228.276 & 374 & .610 & & \\
Bireycilik-Toplulukçuluk & Toplam & 234.227 & 379 & & & \\
& Kümeler Arası & 12.398 & 5 & 2.480 & & \\
& Kümeler İçi & 230.082 & 374 & .615 & & \\
\hline
\end{tabular}

$* \mathrm{p}<0.05$

Çalışmaya katılan bireyler arasında gelir gruplarına göre kalite odaklılık $(p=.000)$, marka odakl1l1k $(\mathrm{p}=.034)$, çeşit karmaşası $(\mathrm{p}=.001)$ ve bireycilik-toplulukçuluk $(\mathrm{p}=.001)$ faktörlerinde anlamlı farklılık bulunmuş, kalan üç faktörde meslek gruplarına göre anlamlı farklılık bulunamamıştır. Tablo 7'te anlamlı farklılık katsayıları gösterilmiştir. Hangi gelir grupları arasında farklılık olduğunu tespit etmek için yapılan Tukey testinin sonucuna göre 5000 TL ve üzeri gelir grubundaki katılımciların $(\overline{\mathrm{X}}=3.3426)$ kalite odakl1lık düzeyinin 2001-3000 TL gelir grubundaki katılımc1lardan $(\overline{\mathrm{X}}=3.0606)$ ve $1404 \mathrm{TL}$ ve altı gelir grubundaki katılımcılardan $(\overline{\mathrm{X}}=3.0226)$ anlamlı derecede yüksek olduğu belirlenmiştir. 3001 - 4000 TL gelir kümesindeki katılımcıların $(\overline{\mathrm{X}}=3.2875)$ kalite odaklılık düzeyinin $1404 \mathrm{TL}$ ve altı gelir grubundaki katılımcilardan $(\overline{\mathrm{X}}=3.0226)$ anlamlı derecede yüksek olduğu saptanmıştır. $1404 \mathrm{TL}$ ve altı gelir grubundaki katılımcıların $(\overline{\mathrm{X}}=2.6245)$ marka odaklılık düzeyinin 2001-3000 TL gelir grubundaki kat1limcilardan ( $\overline{\mathrm{X}}=2.2973)$ anlamlı derecede yüksek olduğu görülmüştür. $5000 \mathrm{TL}$ ve üzeri gelir grubundaki katılımcıların $(\overline{\mathrm{X}}=3.4167)$ çeşit karmaşası düzeyinin 2001-3000 TL gelir grubundaki kat1lımcilardan ( $\overline{\mathrm{X}}=2.8402)$ ve 1404-2000 TL gelir grubundaki katılımcılardan $(\bar{X}=2.6667)$ anlamlı derecede yüksek olduğu belirlenmiştir. 3001 - 4000 TL gelir kümesindeki katılımcıların $(\overline{\mathrm{X}}=3.8267)$ bireycilik-toplulukçuluk düzeyinin $1404 \mathrm{TL}$ ve altı gelir grubundaki katılımcılardan $(\overline{\mathrm{X}}=3.4410)$ anlamlı derecede yüksek olduğu saptanmıştır.

Tablo 8

Hofstede Kültürel Boyutları ile Tüketici Tarzları Envanteri'ne Ait Korelasyon Katsayıları

\begin{tabular}{lcc}
\hline Pearson Korelasyon & Tüketici Tarzları Envanteri & Hofstede Kültürel Boyutları \\
\hline Tüketici Tarzları Envanteri & & \\
Hofstede Kültürel Boyutları & $.188^{* *}$ & \\
Ortalama & 2.8974 & 2.7882 \\
Standart Sapma & .45299 & .53843 \\
\hline
\end{tabular}

$* * \mathrm{p}<0.01$

Ana değişkenler arasındaki ilişkileri gözlemleyebilmek amacıyla korelasyon analizi uygulanmıştır. Tablo 8'de basit korelasyon değerlerinden görüldüğü üzere Hofstede'nin kültürel boyutları ile tüketici tarzları envanteri ana değişkenleri arasında $p<.01$ düzeyinde pozitif yönde çok güçlü bir ilişki bulunmaktadır.

Tablo 9

Tüm Faktörlere Ait Korelasyon Katsayıları, Ortalama ve Standart Sapma Değerleri

Pearson Korelasyon
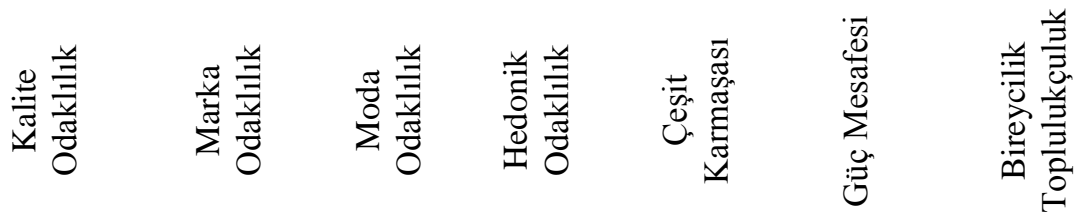

Kalite Odakl1lık

Marka Odaklılık 


\begin{tabular}{lccccccc} 
Moda Odaklılık & $.350^{* *}$ & $.405^{* *}$ & & & & & \\
Hedonik Odaklılık & $.182^{* *}$ & .076 & $.202^{* *}$ & & & & \\
Çeşit Karmaşası & $.302^{* *}$ & $.114^{*}$ & .030 & $.178^{* *}$ & & & \\
Güç Mesafesi & .004 & $.325^{* *}$ & $.127^{*}$ & .054 & -.066 & & \\
Bireycilik Toplulukçuluk & $.186^{* *}$ & -.028 & -.016 & $.141^{* *}$ & $.117^{*}$ & -.078 & \\
Ortalama & 3.155 & 2.481 & 2.947 & 2.896 & 3.008 & 1.976 & 3.600 \\
Standart Sapma & 0.548 & 0.733 & 0.816 & 0.601 & 0.984 & 0.786 & 0.800 \\
\hline
\end{tabular}

$* \mathrm{p}<0.05 \quad * * \mathrm{p}<0.01$

Alt değişkenler arasındaki ilişkileri gözlemleyebilmek için korelasyon analizi uygulanmıştır. Tablo 9'da basit korelasyon değerlerinden görüldüğü üzere Hofstede'nin kültürel boyutlarından güç mesafesi ile tüketici tarzları envanterinde yer alan boyutlardan kalite odakl111lık, hedonik odakl111lık ve çeşit karmaşası değişkenleri arasında $p<.05$ ve $p<.01$ düzeyinde anlamlı bir ilişki bulunmamaktadır. Yine aynı tabloya bakıldığında Hofstede'nin kültürel boyutlarından bireycilik-toplulukçuluk ile tüketici tarzları envanterinde yer alan boyutlardan moda odaklılık ve marka odaklılık değişkenleri arasında $\mathrm{p}<.05$ ve $\mathrm{p}<.01$ düzeyinde anlamlı bir ilişki bulunmadığı görülmektedir. Hofstede'nin kültürel boyutlarından güç mesafesi ile tüketici tarzları envanteri boyutlarından marka odakl111lık ve moda odaklıl1lık değişkenleri arasında $\mathrm{p}<.05$ ve $\mathrm{p}<.01$ düzeyinde pozitif yönlü anlamlı ilişki bulunmaktadır. Hofstede'nin kültürel boyutlarından bireycilik-toplulukçuluk ile tüketici tarzları envanteri boyutlarından kalite odaklılık, hedonik odaklılık ve çeșit karmaşası değişkenleri arasında $\mathrm{p}<.05$ ve $\mathrm{p}<.01$ düzeyinde pozitif yönlü anlamlı bir ilişki bulunduğu görülmektedir.

Sonuçlar incelendiğinde Hofstede'nin kültürel boyutları ile satın alma tarzları arasında pozitif yönlü bir ilişki olduğu, satın alma tarzlarının demografik özelliklere göre farklılık gösterdiği ve yine Hofstede'nin kültürel boyutlarının demografik özelliklere göre farklılık gösterdiği görülmüştür.

\section{Sonuç, Tartışma ve Öneriler}

Araştırmanın temel amacı, birçok farklı örneklem kümesi ve farklı kültürde araştırılmış olan tüketici karar verme tarzlarını Ușak Üniversitesinde ve farklı bir değișken olan Hofstede'nin kültürel boyutları ile birlikte inceleyerek ilişkilerini ortaya koymaktır. Tüketicinin karar verme tarzı başka bir deyişle tüketicinin karakteri olarak kabul edilmektedir (Sproles ve Kendall, 1986). Karar verme tarzları tüketicilerin alışveriş yapma şekillerini açıklayan zihinsel bir süreç olarak belirtilmektedir. Araştırmada karar verme tarzları ve kültürel boyutlar, giyim endüstrisinde tüketicilerin alışveriş tutumları çerçevesinde incelenmiştir.

Demografik özellikler incelendiğinde, evli katılımcılar kümesinin bekâr katılımcılar kümesine oranla daha toplulukçu bir yapıya sahip olduğu görülmektedir. Evli bireylerin çekirdek topluluk olan aile sorumluluğunu üstlenmiş olmaları, iş-çevre çatışmalarının azlığı, aile ve yaşam tatminlerinin yüksek olması (Coşkuner ve Şener, 2013) ve toplulukla uyum içerisinde olmanın aileleri için oluşturduğunu düşündükleri güvenlik duvarı hissi dolayısıyla toplulukçu yaklaşımlarının bekâr katılımcılara göre yüksek düzeyde olması beklenen bir sonuçtur. Evli katılımcıların toplulukçu tutumlarının altında yatan diğer bir sebep de ailelerini sosyo-ekonomik belirsizliklerden korumak için toplumla uyum içerisinde bulunmaları gerektiğini düşünmeleri olabilir. Bekâr katılımcıların moda odaklılık düzeylerinin evli katılımcılara göre yüksek çıkması ise bekâr bireylerin henüz eşlerini bulamamış olduklarını düşünerek sürekli bir kendini beğendirme durumunda olmaları şeklinde açıklanabilir.

18-33 yaş grubu bireylerin yaşça kendilerinden önemli derecede olgun olan $42-57$ yaş grubu bireylere göre daha fazla moda odaklı olmaları evli ve bekâr katılımcı grubundaki eş bulup bulmamış olma durumuyla aynı minvalde ifade edilebilir. Patlama kuşağı ve öncesi kuşağa mensup 66 yaş üstü bireylerin güç mesafesi düzeylerinin $\mathrm{Y}$ ve $\mathrm{Z}$ kuşaklarına mensup 18-33 yaş grubu bireylerden çok daha fazla olması, patlama kuşağı ve öncesi kuşakların katı otorite ve emir komuta zincirini olumlu karşıladıkları gibi önemli bir veriyi ortaya koymaktadır. 
İlköğretim mezunlarının güç mesafesi düzeyinin daha üst öğrenim gruplarına göre fazla olması ve öğrenim durumu arttıkça güç mesafesi düzeyinin azalması, kişinin bilgi ve donanımı arttıkça kendini o oranda ifade edebilme ve kabul görme ihtiyacı ile açıklanabilir. En yüksek eğitim grubuna mensup kümelerin kendilerinden düşük eğitim gruplarından daha fazla toplulukçu olmaları da entelektüel olarak belli bir düzeye gelmiş bireylerin toplum birliğini ve toplumsal düzeni daha fazla önemsedikleri verisini sunmaktadır.

Memur kümesinin giyim konusunda kalite odaklllık düzeyinin diğer meslek kümelerine göre yüksek olması (Aktuğlu ve Temel, 2006), sürekli terfi şansı sunan bir meslek olması ve bu konuda bırakılan görsel izlenimin de dikkate alınması ile ilgili bulunması kuvvetle muhtemeldir. Çalışmayan ve öğrenci bireylerin çeşit karmaşası düzeylerinin yüksek olması, kıyafet konusunda iş yeri kıyafet yükümlülükleri gibi henüz normatif bir düzen içerisinde olmamalarından kaynaklanabilir. Esnaf ve işçilerin güç mesafesi düzeylerinin memurlardan yüksek olması durumu, yasal normlarla düzenlenmiş görevde yükselme şansları olmayan esnaf ve işçilerin aksine bu şansı bulunan ve görevde yükselmek için kendilerini ifade edebilecekleri, gerçekleştirebilecekleri dar güç aralığına sahip şartlara ihtiyaç duyan memurların, geniş güç aralığına sahip katı otorite ve emir komuta zincirine maruz kaldıkları ve durumdan memnun olmadıkları sonucunu sunabilmektedir. Sonuçlara göre memur kümesinin daha toplulukçu olması, topluma aykırı görünmenin mesleki olarak yükselmelerinin önüne geçeceği ve toplumca kabul görmeyen seçimler yaparlarsa sürekli birlikte bulunmak zorunda olduğu iş arkadaşları ile onarılamaz sorunlar yaşayacağı kaygısı taşıması şeklinde yorumlanabilir.

Katılımcılardan 5000 TL ve üstü gelir grubunun kalite odaklılık düzeyinin özellikle araştırmadaki en alt gelir gruplarının kalite odaklılık düzeylerinden fazla olması, kaliteli ürünlerin genelde daha pahalı olması nedeniyle direkt satın alma gücü ile ilişkilendirilebilir. Araştırmadaki en düşük gelir grubunun marka odaklılık düzeyinin diğer gelir gruplarına göre fazla olması, bu alt gelir grubuna mensup bireylerin taşıdıkları elbiselerin markalarına paralel olarak önemsenme ihtiyacı hissettiklerini gösterebilir (Grant ve Stephen, 2005). 5000 TL ve üstü gelir grubunun çeşit karmaşası düzeyinin araştırmadaki en alt gelir gruplarının çeşit karmaşası düzeylerinden fazla olması, satın alma gücünün yüksek olması dolayısıyla herkeste olmayan giyim ürünlerini ayırt edebilme ve bulma çabası ile ilişkilendirilebilir.

Alt faktörlerin incelendiği korelasyon analiz sonuçlarına göre katı hiyerarşi ve emir komuta zincirini makul bulan kümelerin marka ve moda odaklılık ile ilişkisi $\mathrm{p}<.05$ ve $\mathrm{p}<.01$ anlamlılık düzeyinde pozitif çıkmıştır. Bu da katı hiyerarşi ve emir komuta zincirini makul bulan kümelerin dış görünümlerine önem verdiklerini göstermektedir. Yine aynı analiz sonucunda toplulukçu bireylerin kalite odaklılık, hedonik odaklılık ve çeşit karmaşası ile ilişkisinin $\mathrm{p}<.05$ ve $\mathrm{p}<.01$ anlamlılık düzeyinde pozitif çıktığı görülmüştür. Bu veri de bize toplumsal düzene daha bağlı olan bireylerin zevklerine uygun, kaliteli giyinmeyi tercih ettikleri ancak giyim ürünlerini seçmekte zorlandıkları sonucunu sunmaktadır. Giyim ürünlerini seçmekte zorlanmalarının sebebi bireylerin kendi tercihleri yerine mensubu olduğu toplulukça kabul görecek kıyafetleri satın almak zorunda hissetmeleri olabilir (Beaudoin ve Lachance, 2006).

Araştırmanın sonuçlarına göre, çalışmanın temel amacı olan Hofstede'nin kültürel boyutları ile tüketicilerin satın alma tarzları arasında ilişki pozitif yönlü bulunmuştur. Bu da bireylerin toplumla ne derece yakın ilişkide oldukları ya da olmadıklarının ve yaşadıkları çevrede kendilerini ne kadar ifade edebildikleri, önemsendiklerinin ya da önemsenmediklerinin giyim tercihlerini yapmalarında önemli faktörler olduğu ve satın alma alışkanlığını etkilediği verisini ortaya koymuştur. Bu veri Akyıldız (2008) tarafından yapılan ve özgüven ile marka bağlılığı arasındaki ilişkiyi inceleyen çalışma, Çetin'in (2016) gelir düzeyi ile marka bağımlılığı ilişkisini ölçtüğü çalışma ve Özden'in (2019) dış güven ile marka beğenirliği ilişkisini analiz ettiği çalışmayla uyum göstermektedir.

Tüketici satın alma tarzlarının ve söz konusu tarzların Hofstede'nin kültürel boyutlarıyla ilişkisinin incelenmesi amacıyla yapılan bu çalışma literatüre ve sektörle ilgilenen birey ve işletmelere önemli katkılar sağlamaktadır. Araştırmanın sonuçları Türk tüketicileri için etkin bir tasnif aracı 
olabilir. İşletmenin, tüketicilerin satın alma tarzlarını değerlendirebilmesi, böylelikle akılcı bir sistem yaklaşımı ile hedef pazarını bölümlere ayırabilmesi ve oluşturduğu her bir bölüm için ayrı bir yöntem ya da yöntemler grubu oluşturarak rekabet üstünlüğünü sağlaması amacıyla kullanılabilir.

Çalışmanın en büyük kısıtı, kolayda örnekleme yöntemiyle belirlenen tümü Uşak Üniversitesi mensubu katılımcılardan edinilen veriler ile yapılmış olmasıdır. İleriki çalışmalarda temsil oranı daha yüksek örnekleme yöntemleri ve örneklemler ile genellenebilirlik açısından daha güçlü veriler elde edilebilir.

\section{Kaynaklar}

Aktuğlu, I. K. ve Temel, A. (2006). Tüketiciler markaları nasıl tercih ediyor? (Kamu sektörü çalışanlarının giysi markalarını tercihini etkileyen faktörlere yönelik bir araştırma). Selçuk Üniversitesi Sosyal Bilimler Enstitüsü Dergisi, (15), 43-59

Akyıldız, M. (2008). Özgüven duygusu marka bagliligini gercekten artirir mi?. Ege Academic Review. 10. 933-950. 10.21121/eab.2010319623.

Beaudoin, P. and Lachance, M. J. (2006). "Determinants of adolescents' brand sensitivity to clothing", Family and Consumer Sciences Research Journal, Vol.34, No.4

Büyüköztürk, Ş. (2002). Sosyal bilimler için veri analizi el kitabı. Ankara: Pegem A Yayıncılık.

Büyüköztürk, Ş., Kılıç Çakmak, E., Akgün, Ö. E., Karadeniz, Ş., ve Demirel, F. (2008). Bilimsel araştırma yöntemleri. Ankara: Pegem Akademi

Coşkuner, S. ve Şener, A. (2013). Akademisyenlerin iş ve aile karakteristiklerinin evlilik, aile ve yaşam tatmini ile ilişkisi: İş ve aile çatışmasının aracı rolü. Hacettepe Üniversitesi Sosyolojik Araştırmalar E-Dergisi, 21, 1-25.

Çetin, K. (2016). Kadın tüketicilerin giysi satın alma davranışları ve marka bağımlılığı. Ahi Evran Üniversitesi Sosyal Bilimler Enstitüsü Dergisi, 2 (2), 22-40

Dursun, İ., Alnıaçık, Ü. ve Tümer Kabadayı, E. (2013). Tüketici karar verme tarzları ölçeği: Yapısı ve boyutları. Uluslararası Yönetim İktisat ve İsletme Dergisi, 9 (19), 293-304

Durvasula, S., Lysonski, S. and Andrews, J. G. (1993). Cross-cultural generalizability of a scale for profiling consumer's decision making styles. The Journal of Consumer Affairs, 27 (1), 55-65

Fan, J. X. and Xiao, J. (1998). Consumer decision making styles of young-adult Chinese. The Journal of Consumer Affairs, 32 (2), 275-294.

Gary P. Braun and Ramon P. Rodriguez Jr. (2008). Earnings management and accounting values: A test of gray (1988). Journal of International Accounting Research. 7 (2), 1-23.

Grant I.J. and Stephen G.R. (2005). "Buying behavior of "tweenage" girls and key societal communicating factors influencing their purchasing of fashion clothing", Journal of Fashion Marketing and Management. 9(4), 450-467.

Hafstrom, J. L., Chae, J. S. and Chung, Y. S. (1992). Consumer decision making styles: comparison between United States and Korean young consumers. Journal of Consumer Affairs, 26 (1), $146-158$.

Hair, J. F., Black, W. C., Babin, B. J., Anderson, R. E. and Tatham, R. L. (2013). Multivariate data analysis. Pearson Education Limited. 
Hiu, A. S. Y., Siu, N. Y. M., Wang, C. C. L. and Chang, L. M. K. (2001). An investigation of decision-making styles of consumers in China. Journal of Consumer Affairs, 35 (2), 326-345.

Hofstede, G. (1984). Culture's consequences: International differences in work-related values.5. Sage.

Karasar, N. (2018). Bilimsel araştırma yöntemleri (33. baskı). Ankara: Nobel Yayıncılık.

Kavas, A. ve Yesilada, F. (2007). Decision making styles of young Turkish consumers. European Journal of Economics, Finance and Administrative Sciences, 9 (11), 73-85

Lysonski, S., Durvasula, S. ve Zotos, Y. (1995). Consumer-decision making styles: a multi-country investigation. European Journal of Marketing, 30 (12), 10-21

Mitchell, V. W. and Bates, L. (1998). UK consumer-decision making styles. Journal of Marketing Management, 14 (2), 199-225.

Mooij, M. and Hofstede, G. (2002). Convergence and divergence in consumer behavior: implications for international retailing. Journal of Retailing, 78, 85-110.

Nunnally, J.C. (1967). Psychometric theory. New York: Mc-Graw-Hill Book Company.

Odabaşı, Y. ve Bariş, G. (2002). Tüketici davranışı. İstanbul: Mediacat.

Özden, A. (2019). Kadın tüketicilerin özgüven düzeyleri ile tercih ettikleri hazır giyim markalarına yönelik marka beğenirlik düzeyleri arasındaki ilişki üzerine bir araştırma. International Review of Economics and Management, 7 (1) , 115-138. DOI: 10.18825/iremjournal.537707

Sargut, S. (2001). Kültürlerarası farklılaşma ve yönetim. (2. Bask1), Ankara: İmge Yayıncılık.

Sproles, G. B. and Kendall, E. L. (1986). A methodology for profiling consumers' decision making styles. The Journal of Consumer Affairs, 20(2), 267-279.

Steger, U., Schindel, C. ve Krapf, H. (2002). The experience of emas in three european countries: A cultural and competitive analysis. Business Strategy and the Environment, 11, 32-42

Tavşancıl, E. (2006). Tutumların ölçülmesi ve SPSS ile veri analizi. (3. Bask1). Ankara: Nobel

Ünal, S. ve Erciş, A. (2006). Tüketicilerin kişisel değerlerinin satın alma tarzları üzerindeki etkisi. Ticaret ve Turizm Ë̆itim Fakültesi Dergisi, 1, 23-45.

Walsh, G., Mitchell, V. W. and Thurau, T. H. (2001). German consumerdecision making styles. The Journal of Consumer Affairs, 35 (1), 73-95.

Yoo, B., Donthu, N. and Lenartowicz, T. (2011). Measuring Hofstede's five dimensions of cultural values at the individual level: Development and validation of CVSCALE. Journal of International Consumer Marketing, 23(3-4), 193-210. 


\section{Extended Abstract}

\section{Introduction}

As the speed of change increases in every field in the world, the physical and psychological elements that individuals are affected have also increased. The Cultural Dimensions theory of Geert Hofstede, one of the psychological factors affecting the decisions of individuals, has been a research resource for many industries. The cultural dimensions are among the factors that the decision makers who determine the marketing strategies in the clothing sector pay attention to the most. There are many reasons for the sales success of any product or product group. These reasons can be physical or psychological. Cultural dimensions come into play at this stage. Although the dominant features of the culture involved are effective on consumer behavior, they do not affect each consumer in the same way, and each of the cultural dimensions may have different effects on the consumer or consumer groups. In our study, we tried to observe the relationship between two cultural dimensions (power distance and individualism-collectivism) and purchasing habits based on the existing cultures of the participants of Uşak University. The scales with qualitatively involved dimensions were used and it was aimed to determine the attitudes of the participating consumer individuals based on these qualities. Most of the researches carried out to date have been done to test consumers' purchasing styles using the Consumer Styles Inventory (TTE) dimensions developed by Sproles and Kendall (1986) on different samples. The main difference that distinguishes this research from other researches is that the TTE dimensions and Hofstede's cultural dimensions (Power distance and individualismcollectivism) are examined together for the first time. In this way, it has been tried to evaluate the variables observed or tried to be determined, to reveal their degree of influence and to reveal the relationships between each other. The findings of this research will be a pioneer and source in the literature for similar studies to be carried out later.

\section{Method}

With the model used in the research the relationship between five dimensions from TTE dimensions ; perfectionism, recreational, fashion conscious, confused by overchoice and brand conscious, and the individualism-collectivism and power distance from Hofstede's cultural dimensions are measured. In the study, five dimensions from Sproles and Kendall's eight main features, which were defined in 1986 to determine the decision making styles of consumers, and two of the five dimensions created by Yoo, Donthu and Lenartowicz (2011) adapting Hofstede's five-dimensional cultural values scale which are theoretically considered appropriate from the framework of experts were used. In this research, convenience sampling method was preferred. In order for the sample to represent the population better and to increase the generalizability rate by reaching a more heterogeneous structure, a larger sampling frame of 750 people, consisting of students, employees and educators, has been presented. As a result of the questionnaire application, 463 people answered the questionnaires, 83 of which were eliminated due to deficiencies and inconsistencies, and a total of 380 samples were subjected to analysis and tests. The scale consists of 38 items and 7 dimensions. The expressions in both scales are rated as 5-point Likert (1: Strongly Disagree, 2: Disagree, 3: Undecided, 4: Agree, 5: Strongly Agree). In Table1, demographic characteristics of the sample can be seen with the percentage.

\section{Result}

Descriptive statistical methods (percentage, frequency, standard deviation, mean) were used to reach demographic information in the analysis of the data obtained with the scale of the study. In order to determine the normality distribution, skewness and kurtosis coefficients were reached with the statistical analysis method frequently used in social sciences, and all skewness and kurtosis coefficients were between +1 and -1 (Hair, Black, Babin, Anderson and Tatham, 2013) and therefore the data were found to be normally distributed. As can be seen in Table 2, as a result of calculating the Cronbach's Alpha internal consistency coefficient calculated to test the internal consistency reliability 
in scale, 7 factors were found to be above .60 reliability value accepted in social sciences. Values of .60 and above are acceptable reliability value ranges for research in social sciences (Nunnally, 1967). In order to examine the differences in the scale items according to the demographic characteristics of the participants, t-test and one-factor ANOVA statistical method were used for independent samples (Büyüköztürk, 2002). Pearson correlation analysis was used to measure the bilateral relationship between variables.

When the results are evaluated, it is seen that there is a positive relationship between the cultural dimensions of Hofstede and the purchase styles, the purchase styles differ according to the demographic characteristics and the cultural dimensions of Hofstede differ according to the demographic characteristics.

\section{Discussion and Conclusion}

According to the results of the research, the relationship between the cultural dimensions of Hofstede, and the purchasing styles of consumers, which is the main purpose of the study was found to be positive. This revealed the data of how close individuals are or are not with the society and how much they can express themselves in the environment they live in, whether they are cared or ignored, are important factors in making their clothing choices and affect their purchasing habit. This study, which was conducted to examine consumer purchasing styles and the relationship of these styles with Hofstede's cultural dimensions, contributes significantly to the literature and individuals and businesses interested in the sector. The results of the research can be an effective sorting tool for Turkish consumers. It can be used to enable the business to evaluate consumers' purchasing styles, thereby dividing the target market into segments with a rational system approach, and to provide a competitive advantage by creating a separate method or group of methods for each department. In future studies, stronger data can be obtained in terms of generalizability with sampling methods and samples with higher representation rates. 